\title{
Loss of $\gamma$-Secretase Function Impairs Endocytosis of Lipoprotein Particles and Membrane Cholesterol Homeostasis
}

\author{
Irfan Y. Tamboli, ${ }^{1}$ Kai Prager, ${ }^{1}$ Dietmar R. Thal, ${ }^{3}$ Karin M. Thelen, ${ }^{2}$ Ilse Dewachter, ${ }^{4}$ Claus U. Pietrzik, ${ }^{5}$ \\ Peter St. George-Hyslop, ${ }^{6}$ Sangram S. Sisodia, ${ }^{7}$ Bart De Strooper, ${ }^{8}$ Michael T. Heneka, ${ }^{1}$ Mikhail A. Filippov, ${ }^{9}$ \\ Ulrike Müller, ${ }^{9}$ Fred van Leuven, ${ }^{4}$ Dieter Lütjohann, ${ }^{2}$ and Jochen Walter ${ }^{1}$ \\ Departments of ${ }^{1}$ Neurology and ${ }^{2}$ Clinical Pharmacology, University of Bonn, 53127 Bonn, Germany, ${ }^{3}$ Institute of Pathology, University of Ulm, 89081 Ulm, \\ Germany, ${ }^{4}$ Department of Human Genetics, Experimental Genetics Group, Katholieke Universiteit (K.U.) Leuven, 3000 Leuven, Belgium, ${ }^{5}$ Department of \\ Physiological Chemistry and Pathobiochemistry, University of Mainz, 55099 Mainz, Germany, ${ }^{6}$ Center of Research in Neurodegenerative Diseases, \\ University of Toronto, Toronto, Ontario, Canada M5S 3H2, ${ }^{7}$ Department of Neurobiology, Pharmacology, and Physiology, University of Chicago, Chicago, \\ Illinois 60637, ${ }^{8}$ Center for Human Genetics, Flanders Interuniversity Institute for Biotechnology (VIB4) and K.U. Leuven, 3000 Leuven, Belgium, and \\ ${ }^{9}$ Institute for Pharmacy and Molecular Biotechnology, University of Heidelberg, 69120 Heidelberg, Germany
}

Presenilins (PSs) are components of the $\gamma$-secretase complex that mediates intramembranous cleavage of type I membrane proteins. We show that $\gamma$-secretase is involved in the regulation of cellular lipoprotein uptake. Loss of $\gamma$-secretase function decreased endocytosis of low-density lipoprotein (LDL) receptor. The decreased uptake of lipoproteins led to upregulation of cellular cholesterol biosynthesis by increased expression of CYP51 and enhanced metabolism of lanosterol. Genetic deletion of PS1 or transgenic expression of PS1 mutants that cause early-onset Alzheimer's disease led to accumulation of $\gamma$-secretase substrates and mistargeting of adaptor proteins that regulate endocytosis of the LDL receptor. Consistent with decreased endocytosis of these receptors, PS1 mutant mice have elevated levels of apolipoprotein $\mathrm{E}$ in the brain. Thus, these data demonstrate a functional link between two major genetic factors that cause early-onset and late-onset Alzheimer's disease.

Key words: presenilin; lipoprotein uptake; apo E; SREBP2; cholesterol; APP

\section{Introduction}

Cellular membrane cholesterol levels are controlled by de novo synthesis, storage in form of cholesterol esters, and the uptake and release of cholesterol in complexes with lipoproteins (Brown and Goldstein, 1997). Low cellular cholesterol levels induce biosynthesis by complex transcriptional and posttranslational mechanisms involving proteolytic processing of sterol regulatory element binding proteins (SREBPs) to increase expression of enzymes involved in cholesterol synthesis. Higher cholesterol levels inhibit the proteolytic processing of SREBPs and thereby decrease cellular cholesterol biosynthesis (Goldstein et al., 2006).

The internalization of extracellular cholesterol/lipoprotein complexes by receptor-mediated endocytosis involves adaptor proteins that bind to specific amino acid motifs in their cytoplas-

Received June 10, 2008; revised Sept. 1, 2008; accepted Sept. 23, 2008.

This work was supported by the Deutsche Forschungsgemeinschaft (SFB 645, FOR177), the Federal Ministry of Education and Research of Germany (01GI0708) and the BONFOR program of the University of Bonn to J.W. We thank Drs. C. Haass, C. Noviello, L. D’Adamio, P. M. Mathews, S. Mishra, and M. Traub for providing cDNAs and antibodies. We thank H. Hampel and E. Barth for expert technical assistance and Dr. N. Kukoc-Zivojnov for quantification of neurons and comments on this manuscript.

Correspondence should be addressed to Dr. Jochen Walter, Molecular Cell Biology, University of Bonn, SigmundFreud-Str. 25, 53127 Bonn, Germany. E-mail: jochen.walter@ukb.uni-bonn.de.

DOI:10.1523/JNEUROSCI.2635-08.2008

Copyright $\odot 2008$ Society for Neuroscience ～0270-6474/08/2812097-10\$15.00/0 mic domains (Herz and Bock, 2002; Jeon and Blacklow, 2005). In the human brain, cholesterol is mainly transported in high density lipoprotein particles that predominantly contain the apolipoprotein E (apo E). Notably, apo E has been linked to Alzheimer's disease $(\mathrm{AD})$, implicating that altered transport and metabolism of lipids in the brain could contribute to neurodegeneration (Kennedy et al., 2003; Tanzi and Bertram, 2005).

Whereas the apo E4 allele is a major risk factor for late-onset $\mathrm{AD}$, mutations in the presenilin (PS) genes are a major cause of early-onset familial AD (FAD) (Kennedy et al., 2003; Tanzi and Bertram, 2005). PSs are the catalytic components of $\gamma$-secretase complexes that mediate cleavage of type I membrane proteins (Selkoe and Kopan, 2003; Parks and Curtis, 2007). The cleavage of the $\beta$-amyloid precursor protein (APP) by $\gamma$-secretase results in generation of the amyloid $\beta$-peptide $(\mathrm{A} \beta)$, which accumulates in extracellular deposits during the pathogenesis of AD (Selkoe, 2001). In addition to APP, a growing number of additional substrates for $\gamma$-secretase have been identified (Selkoe and Wolfe, 2007; Spasic and Annaert, 2008). The cleavage of these proteins is apparently regulated by preceding shedding of their ectodomains by other proteases resulting in the generation of membranetethered C-terminal fragments (CTFs) (Struhl and Adachi, 2000). The subsequent intramembranous cleavage of these CTFs by $\gamma$-secretase results in the release of intracellular domains 
(ICDs) from cellular membranes that can serve signaling functions. This process is well understood for Notch signaling where the Notch ICD (NICD) translocates to the nucleus to regulate gene transcription (Sisodia and George-Hyslop, 2002; Selkoe and Kopan, 2003). The importance of this cleavage is demonstrated by the phenotypes of PS knock-out animals that closely resemble that of Notch deficiency (Shen et al., 1997; Wong et al., 1997; Herreman et al., 2000). However, it is far from being clear whether PS-dependent cleavage of other $\gamma$-secretase substrates also serve signaling functions or is also important for more general degradation of membrane proteins (Kopan and Ilagan, 2004; Selkoe and Wolfe, 2007). PS proteins also affect the subcellular trafficking of individual membrane proteins, including APP, TrkA, telencephalin, tyrosinase, and transferrin, but the underlying molecular mechanisms remain unclear (Naruse et al., 1998; Annaert et al., 2001; Wang et al., 2006; Zhang et al., 2006; Parks and Curtis, 2007).

Here, we show that the accumulation of $\gamma$-secretase substrates after partial loss of $\gamma$-secretase function impairs endocytosis of lipoproteins. Importantly, FADassociated mutations of PS1 also induced aberrant endocytosis of apoE.

\section{Materials and Methods}

cDNA constructs, antibodies, and reagents. The constructs encoding APP C99-EGFP (Kaether et al., 2006), Fe65-myc (Pietrzik et al., 2004), and ARH (Noviello et al., 2003) have been described earlier. APP C99-EGFP represents the $\gamma$-secretase substrate derived from APP by $\beta$-secretase cleavage. It also contains a signal sequence that targets the protein into the cell membrane. PS1 wild type (WT) and dominant-negative constructs (PS1 DN) have been described earlier (Capell et al., 2000). AntiLRP1-CT (Pietrzik et al., 2002), anti-ARH (Mishra et al., 2002), and m3.2 antibody against mouse APP (Schmidt et al., 2005) have been described earlier. Anti-LDLR (Abcam), anti-SREBP-2 (Abcam), anti-mouse apo E (Santa Cruz Biotechnology), anti-human apo E (Signet), and antiHMGCoA reductase (Upstate) antibodies were ordered from respective sources and used according to the manufacturers' instructions. All the standard reagents were obtained from Sigma unless mentioned otherwise.

Cell culture and transfection. Embryonic fibroblasts of wild-type (WT) and PS1/PS2 double knock-out (PS dKO) mice were described previously (Nyabi et al., 2002). Additional cell lines were obtained from ATCC. Cells were cultured in DMEM supplemented with 10\% fetal calf serum. Transfection of cells with recombinant cDNA constructs was performed with Lipofectamine according to the manufacturer's instructions (Invitrogen). Clones were selected with $200 \mu \mathrm{g} / \mathrm{ml}$ zeocin (Invitrogen).

Mouse strains. The generation of mice with postnatal neuron-specific deletion of PS1 (PS1n ${ }^{-1-}$ ) has been described previously (Dewachter et al., 2002). Mice with floxed PS1 genes but no expression of Crerecombinase were used as controls. The generation and characterization of transgenic mice expressing mutant PS1A246E under control of the Thy-1 gene promoter have been described earlier (Dewachter et al., 2002). Transgenic mice expressing human PS1 WT or $\Delta \mathrm{E} 9$ mutant have been described previously (Lee et al., 1997). Mice with APP- and APLP2deficient alleles (von Koch et al., 1997; Heber et al., 2000) and APPs $\alpha$ knock-in (APPs $\alpha$-KI) (Ring et al., 2007) were described earlier. APLP2deficient mice with APPs $\alpha$-KI alleles (DKI) were generated by breeding
B
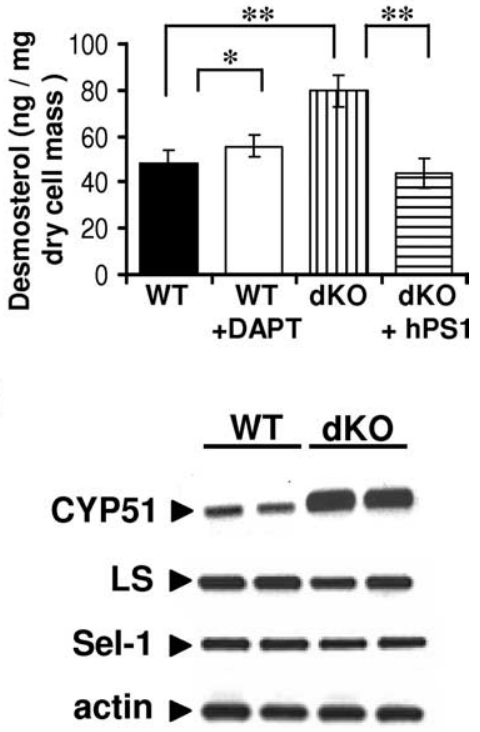

\section{D}

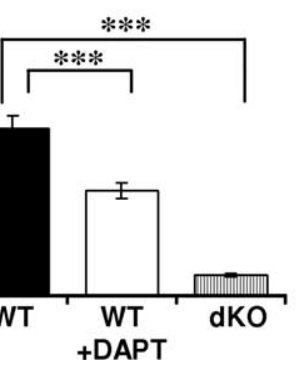

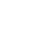

(1)

Figure 1. Increased cholesterol biosynthesis in PS-deficient cells via increased expression CYP51. A-C, MEFs were incubated in the presence or absence of $10 \mu \mathrm{m}$ DAPT for $48 \mathrm{~h}$ where indicated. Cellular concentrations of cholesterol $(\boldsymbol{A})$, desmosterol $(\boldsymbol{B})$, and lanosterol ( $\boldsymbol{C}$ ) were determined by GC-FID ( $\boldsymbol{A})$ and GC-MS ( $\boldsymbol{B}, \boldsymbol{C}$ ), respectively (dKO + hPS1; PS dKO MEFs stably expressing human 1). compared with PS WT cells ( $n=3$ for PS dK0 and PS WT; $p<0.001$ ). Significance values are indicated by asterisks as follows: ${ }^{*} p<0.05 ;{ }^{* *} p<0.01 ;{ }^{* * *} p<0.001$.

APPs $\alpha$-KI with APLP2-deficient animals. We used APPs $\alpha^{+/-}$ APLP2 $2^{-1-}$ interbreeding to obtain littermates of $\mathrm{APLP} 2^{-1-}$ and APPs $\alpha^{-1-} / \mathrm{APLP}^{-1-}$, which were then analyzed. APP/APLP1/APLP2 triple knock-out mice were originally described by Herms et al. (2004).

Human brain material was obtained from the University Hospital of Bonn (Bonn, Germany), and the Municipal Hospital of Offenbach (Offenbach, Germany). Detailed description of the brains is in the supplemental material (available at www.jneurosci.org).

Immunohistochemistry and protein analysis of human and mouse brain. Mouse brains were immersion fixed in $4 \%$ paraformaldehyde. Blocks of the right hemisphere were embedded in paraffin and microtomed into 5 $\mu \mathrm{m}$ sections. Apo E staining was performed as described earlier (Thal et al., 2005). Homogenization of human and mouse brain protein extraction and detection by Western immunoblotting was performed as described previously (Dewachter et al., 2002; Wahle et al., 2006).

Immunocytochemistry. Cells were grown on polylysine-coated glass coverslips and fixed in $4 \%$ paraformaldehyde before processing for immunofluorescence as described previously (Walter et al., 2001). To visualize endocytosis of LDL, $10 \mu \mathrm{g} / \mathrm{ml}$ BODIPY-labeled LDL (Molecular probes) was added to living cells for $10 \mathrm{~min}$ at $37^{\circ} \mathrm{C}$ in DMEM, and cells were fixed after washing. Endocytosis was monitored by fluorescence microscopy.

Reverse transcription (RT) PCR. For the semiquantitative PCR from MEF cells, total RNA was obtained from WT and dKO cells using Trizol (Invitrogen) followed by cDNA synthesis using oligo(dT) primer and SuperScript II reverse transcriptase (Invitrogen). PCR (18 cycles) was performed for the respective cDNAs using the following primer pairs: $\beta$-actin: $5^{\prime}$-TGCGTGACATCAAAGAGAAG-3' and 5'-GCTCATAGCTCTTCTCCAGG-3'; lanosterol synthase: 5'-AGGAAGCAGAGAGCCGATG-3' and 5'-TGATCCCTCTCTCCTGAGC-3'; CYP51: 5' -CTGGACAGCACACATCCTC- $3^{\prime}$ and 5'-CACACACCTGATGTCCTGG-3'; seladin-1: 5'-GAGACACTACTACCACCGAC-3' and 5' -TGTCCACGTAGAGCTCTGC-3'.

For quantitative real-time PCR, mouse brain hemispheres were fixed 
A

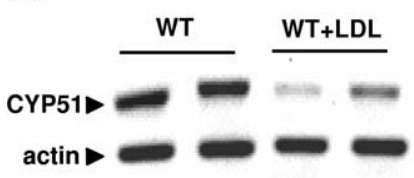

B

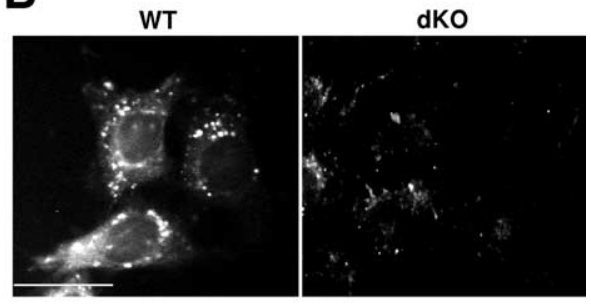

C

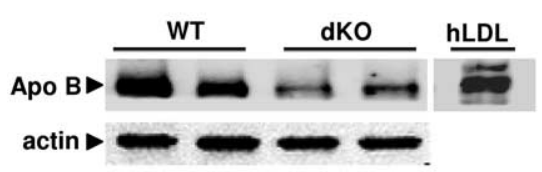

D

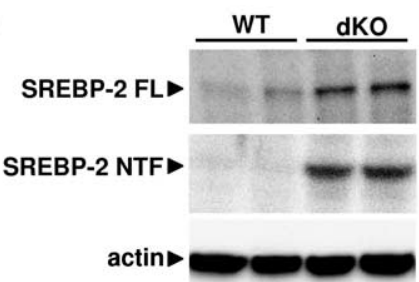

E

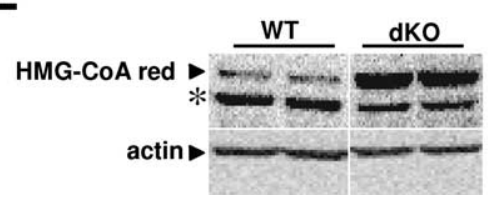

$\mathbf{F}$

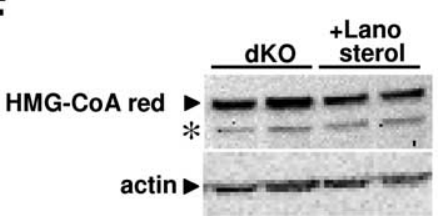

Figure 2. PS deficiency results in decreased endocytosis of lipoproteins and increased expression of SREBP-2.A, Transcriptional regulation of CYP51 by LDL. MEF WT cells were incubated in presence or absence of $10 \mu \mathrm{g} / \mathrm{ml}$ human LDL for $16 \mathrm{~h}$, and expression of CYP51 was analyzed by RT-PCR. The expression of CYP51 mRNA was significantly lower after incubation with exogenous LDL [38.8 $\pm 9.4 \%$ with LDL $(n=3)$ vs $100 \pm 28.3 \%$ without LDL $(n=3), p<0.05]$. B, Cytochemical analysis of BODIPY-LDL endocytosis was performed in WT and PS dKO MEFs as described in the Materials and Methods. Scale bar, $50 \mu \mathrm{m}$. C, Western immunoblotting analysis of cellular apo B-100 levels. Purified human LDL (hLDL) was loaded as a positive control. Quantitation revealed significantly reduced levels of apo B-100 in PS dKO cells $[68.6 \pm 9.2 \%(n=3)$ vs $100 \pm 13.9 \%$ in PS WT cells $(n=3)$, $p<0.05$ ]. D, Expression analysis of SREBP-2 full-length (SREBP-2 FL) and SREBP-2 N-terminal fragment (SREBP-2 NTF) in WT and PS dKO MEFs performed by Western immunoblotting. SREBP-2 FL was detected in crude membrane preparations, whereas SREBP-2 NTF was detected in cytosolic fractions. Quantitation showed significant increases in PS dKO cells for SREBP-2 FL (322.6 \pm $49.3 \%, p<0.01)$ and SREBP-2 NTF $(241.1 \pm 58.0 \%, p<0.01)$ compared with PS WT cells. $E$, Detection of HMG-CoA reductase in WT and PS dKO MEFs by Western immunoblotting. Migration of HMG-COA reductase is indicated by arrowheads. A lower molecular mass species was also detected in both cell types (asterisks). Levels of HMG-CoA reductase were significantly increased in PS dKO cells [240.9 $\pm 8.6 \%$ in PS dKO $(n=3)$ vs $100 \pm 8.5 \%$ in PS WT $(n=3), p<0.001]$. $\boldsymbol{F}$, The treatment of PS dKO MEFs with lanosterol $(25 \mu \mathrm{m}, 48 \mathrm{~h}$ ) decreased the levels of HMG-CoA reductase [71.8 $\pm 6.9 \%$ in LDL-treated $(n=3)$ vs $100 \pm 13.9 \%$ in untreated cells $(n=3) ; p<0.05]$.

in "RNAlater" overnight at $-20^{\circ} \mathrm{C}$. The other hemisphere was snap frozen and kept at $-20^{\circ} \mathrm{C}$ for biochemical analyses. Total mRNA was prepared from the dissected frontal cortex using the RNeasy purification kit, and cDNA was prepared from $2 \mu \mathrm{g}$ of total RNA using Applied Biosystems High Capacity cDNA kit. Real-time PCR was performed using FAM-MGB dye-labeled TaqMan Gene Expression Assays (Applied Biosystems) for LRP1 and for $\beta$-actin as an internal standard according to recommendations of the manufacturer. For quantitation, results were evaluated by the $2^{-\Delta \Delta \mathrm{CT}}$ method.

Biotinylation and endocytosis of lipoprotein receptors. Labeling of cell surface protein has been described earlier (Tamboli et al., 2005). Briefly, cells were incubated on ice with PBS containing $0.5 \mathrm{mg} / \mathrm{ml} \mathrm{EZ-link} \mathrm{sulfo-}$ NHS-biotin (Perbio) for $30 \mathrm{~min}$. Cells were then washed three times with ice-cold PBS supplemented with $20 \mathrm{~mm}$ glycine and finally lysed with STEN buffer containing 1\% NP-40/1\% Triton X-100. Biotinylated proteins were precipitated from cleared lysates with streptavidin-conjugated agarose beads (Sigma) and separated by SDS-PAGE. LDL receptor was then detected by Western immunoblotting. To study LDLR endocytosis, cleavable EZ-link sulfo-NHS-SS-biotin was used (Perbio). After biotinylation, cells were further incubated at $37^{\circ} \mathrm{C}$ for $15 \mathrm{~min}$ to allow endocytosis. Endocytosed LDLR was then analyzed by cleavage of biotin from nonendocytosed LDLR using reducing buffer.

Analysis of cellular sterols. Lipids were extracted with chloroform/ methanol $(2: 1 ; \mathrm{v} / \mathrm{v})$ from cultured cells and dried to constant weight in a
Speedvac (Servant Instruments). $5 \alpha$ Cholestane (Serva Electrophoresis), epicoprostanol (Sigma), and racemic [23,23,24,25-2H4] $24(R, S)$-OHchol (Medical Isotopes) were added as internal standards. After saponification, extraction, and derivatization, sterols were determined as trimethylsilyl-ethers by using gas-liquid chromatography-flame ionization detection (GC-FID) to analyze cholesterol, and GC-mass spectrometry (GC-MS) to measure concentrations of lanosterol, desmosterol, and cholestanol as described previously (Päivä et al., 2005).

Data analysis and statistics. ECL signals were measured and analyzed using an ECL imager (ChemiDoc XRS, Bio-Rad) and the Quantity One software package (Bio-Rad). For quantitation of cellular sterol concentrations, five independent experiments $(n=5)$ were carried out. Statistical analysis was done using Student's $t$ test.

\section{Results \\ Increased cholesterol biosynthesis in PS-deficient cells via transcriptional upregulation of CYP51}

To assess the involvement of $\gamma$-secretase in cellular cholesterol metabolism, we performed a comprehensive analysis of cellular sterols in mouse embryonic fibroblasts (MEFs) of WT and PS1/PS2 double knock-out (PS dKO) mice. PS dKO cells showed increased levels of cholesterol compared with WT MEFs (Fig. $1 A$ ). Stable overexpression of human PS1 (hPS1) in PS dKO cells (see supplemental Fig. 2, available at www.jneurosci.org as supplemental material) partially normalized cholesterol levels to that of WT cells. In addition, the pharmacological inhibition of endogenous $\gamma$-secretase activity in WT MEFs with $N$-[N-(3,5-difluorophenacetyl)-L-alanyl]-S-phenylglycine $t$-butyl ester (DAPT) also led to a significant increase in cholesterol concentrations (Fig. 1A). These data are consistent with previous studies that also indicated an implication of $\gamma$-secretase in the regulation of cellular cholesterol levels (Grimm et al., 2005; Liu et al., 2007).

To further analyze whether the increased cholesterol levels in PS-deficient cells were associated with increased de novo synthesis, we determined the levels of desmosterol, an immediate precursor of cholesterol. Desmosterol concentrations were also increased in the PS dKO cells by 40\%. As observed for cholesterol, transfection of PS dKO cells with hPS1 also decreased levels of desmosterol, whereas treatment of WT cells with DAPT led to increased levels of desmosterol (Fig. $1 B$ ). Cellular levels of cholestanol, a reduction product of cholesterol, and of the hydroxylated derivative 27-OH-cholesterol were also increased in PS-deficient cells (supplemental Fig. 3, available at www. jneurosci.org as supplemental material), indicating that the elevated levels of cholesterol in PS $\mathrm{dKO}$ cells are not caused by impaired downstream metabolism of cholesterol.

The first cyclic metabolite in cholesterol biosynthesis is lanosterol that is generated by cyclization of squalene (supplemental Fig. 1, available at www.jneurosci.org as supplemental material). 
The analysis of lanosterol revealed decreased levels of this precursor in PS $\mathrm{dKO}$ cells compared with WT cells (Fig. 1C). DAPT treatment of WT MEFs also resulted in decreased lanosterol levels (Fig. $1 C)$. The strongly altered levels of lanosterol led us to analyze the mRNA expression of the three enzymes directly involved in lanosterol metabolism. mRNA levels of lanosterol synthase and seladin-1 were not significantly altered in PS $\mathrm{dKO}$ cells compared with WT cells (Fig. 1D). In contrast, mRNA expression of CYP51 was markedly increased in PS $\mathrm{dKO}$ cells, indicating that PS deficiency led to increased cholesterol biosynthesis by upregulation of CYP51 expression, and increased metabolism of lanosterol. To prove whether the increased cholesterol biosynthesis in PS-deficient cells could be reversed by inhibition of CYP51 activity, we tested the effect of itraconazole, a selective inhibitor of CYP51 (Päivä et al., 2005). The treatment with itraconazole increased levels of lanosterol in PS dKO cells, proofing the inhibition of CYP51 (supplemental Fig. 4, available at www.jneurosci.org as supplemental material). We also observed a subtle but highly significant decrease in cholesterol and desmosterol after itraconazole treatment (supplemental Fig. 4, available at www. jneurosci.org as supplemental material). In contrast, altered sterol levels in PS dKO cells were not normalized by the addition of exogenous $\mathrm{A} \beta$ (supplemental Fig. 5, available at www.jneurosci.org as supplemental material).

\section{Loss of $\gamma$-secretase decreases}

lipoprotein uptake

The expression of CYP51 in endothelial cells is suppressed by the uptake of extracellular LDL (Rodríguez et al., 2001). Because we also observed a significant downregulation of CYP51 expression after incubation of WT MEFs with exogenous LDL (Fig. 2A), we speculated that the increased expression of CYP51 in PS $\mathrm{dKO}$ cells might be caused by impaired uptake of extracellular LDL from the cell culture media. WT cells efficiently internalized BODIPY-labeled LDL into cytoplasmic vesicular structures, demonstrating endocytosis of LDL (Fig. $2 B$ ). In contrast, very little internalization of BODIPY-labeled LDL was observed in PS $\mathrm{dKO}$ cells, indicating impaired endocytosis of LDL (Fig. 2 B). To prove this, we analyzed total cellular levels of LDL in PS WT and $\mathrm{dKO}$ cells by Western immunoblotting with an antibody against apolipoprotein B100 (apo B100), a major component of LDL particles in culture serum. Cellular levels of apo B100 were significantly lower in PS dKO cells, also indicating decreased internalization of LDL in PS-deficient cells (Fig. 2C). Consistent with decreased endocytosis of lipoproteins, the cellular levels of sitosterol, an exogenous plant sterol that is associated and internalized

A

B
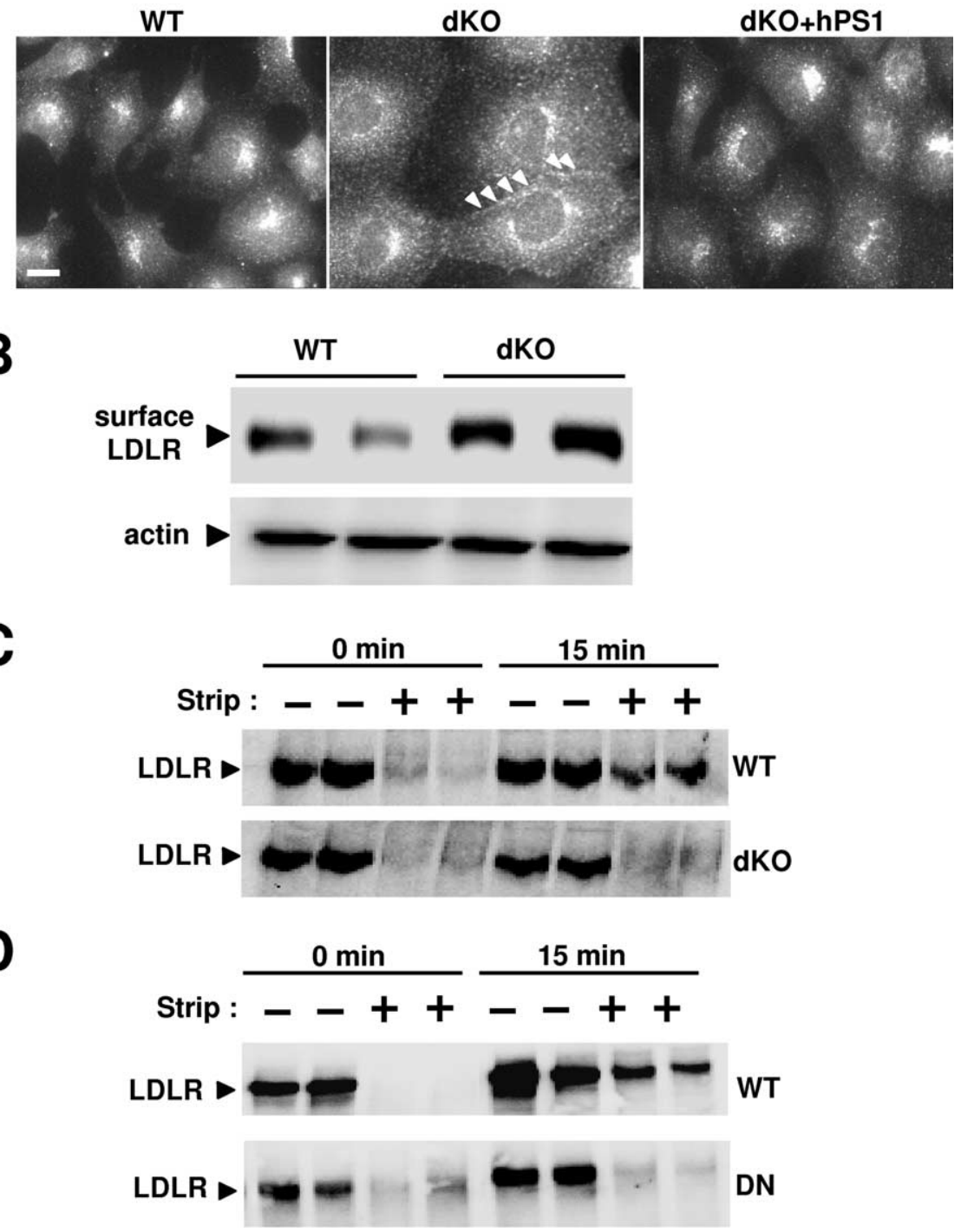

Figure 3. $\gamma$-Secretase-dependent distribution and endocytosis of the LDL receptor. $\boldsymbol{A}$, Presenilin-dependent subcellular localization of LDLR was analyzed by immunocytochemistry. Prominent localization of LDLR at the cell surface in PS dKO cells is indicated by arrowheads. PS dKO cells have altered size and morphology compared with WT cells. These alterations were reverted by reexpression of hPS1. Scale bar, $25 \mu \mathrm{m}$. B, Cell surface proteins were labeled with sulfo-NHS-biotin and precipitated with trol. C, Decreased endocytosis of LDLR in PS-deficient cells. Surface proteins of MEF WT and PS dKO cells were labeled with sulfo-NHS-SS-biotin. Cells were incubated for the indicated time periods at $37^{\circ} \mathrm{C}$ to allow endocytosis, and residual biotin from cell was removed using reducing buffer. Internalized biotin-labeled proteins were precipitated and LDLR was detected by Western immunoblotting (see Materials and Methods section for details). D, LDLR endocytosis analysis in HEK293 cells expressing PS1 WT or a dominant-negative (DN) variant of PS1.

with serum lipoproteins, but not metabolized by mammalian cells, were also significantly reduced in PS dKO cells $(3.5 \pm 0.2$ $\mathrm{ng} / \mathrm{mg}$ dry cell mass in PS dKO $(n=5)$ versus $14.6 \pm 0.5 \mathrm{ng} / \mathrm{mg}$ dry cell mass in PS WT cells, $p<0.001)$. Collectively these data demonstrate an impaired internalization of LDL particles in PSdeficient cells.

Decreased uptake of extracellular LDL should also increase expression of SREBP-2, which itself regulates the expression of CYP51 (Rodríguez et al., 2001). In line with the observed inhibition of LDL uptake, levels of full-length SREBP-2 and its $\mathrm{N}$-terminal fragment that regulates transcription of target genes were significantly increased in PS dKO cells (Fig. 2D). Levels of 

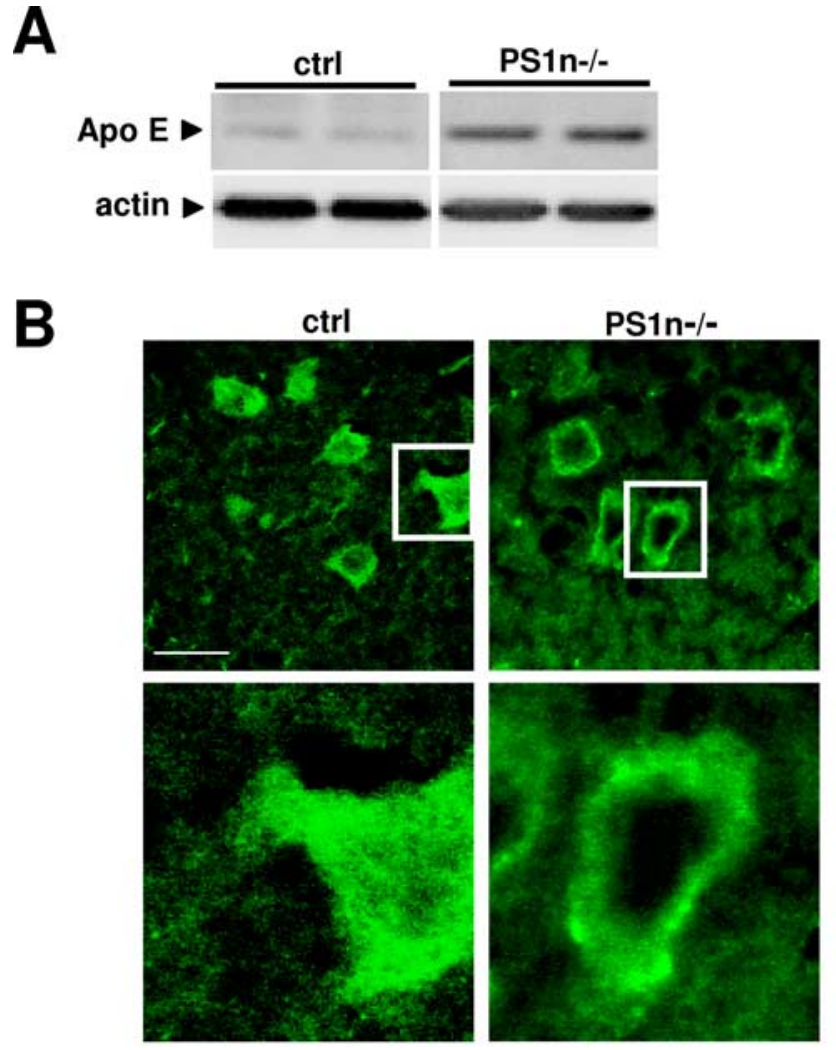

C
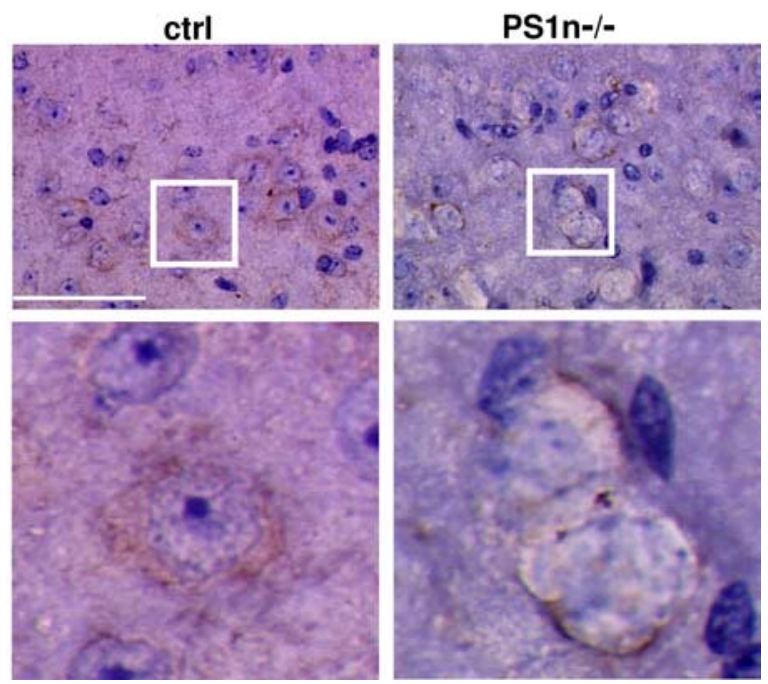

Figure 4. Regulation of apo E levels by PS in mouse brains. $\boldsymbol{A}$, Western blot analysis of apo $\mathrm{E}$ in brains of WT and PS1 conditional knock-out mice (PS1n ${ }^{-1-}$ ) at age of 16 month. As determined by quantitative ECL imaging, apo E levels were $161.8 \pm 55.4 \%$ in PS1n ${ }^{-1-}(n=4)$ versus $100 \pm 20.5 \%$ in PS1 WT mice $(n=4) ; p<0.05$. The effect was sex independent. $\boldsymbol{B}, \boldsymbol{C}$, Neuronal localization of apo $E$ in brain cortices of WT and PS1n ${ }^{-1-}$ mice was analyzed by confocal microscopy $(\boldsymbol{B})$ and immunohistochemistry ( $\boldsymbol{C}$, counterstain with hematoxylin) as described in Materials and Methods. Scale bars, $50 \mu \mathrm{m}$.

HMG-CoA reductase, another target gene, which is upregulated by SREBP-2, were also increased in PS dKO cells (Fig. 2 E). However, levels of HMG-CoA reductase could be also regulated posttranslationally by lanosterol levels (Goldstein et al., 2006). Indeed, addition of exogenous lanosterol significantly decreased HMG-CoA reductase levels in PS dKO cells (Fig. $2 F$ ). Thus, the increase in HMG-CoA reductase levels could also involve stabi- lization of the protein by decreased lanosterol concentrations in PS dKO cells. Together these data indicate that inhibition of $\gamma$-secretase decreased lipoprotein uptake, which in turn led to upregulation of cholesterol biosynthetic enzymes.

\section{Inhibition of $\boldsymbol{\gamma}$-secretase impairs endocytosis of lipoprotein receptors}

We next analyzed the expression of the LDL receptor (LDLR) in WT and PS dKO MEFs. Although LDLR was localized predominantly in juxtanuclear structures in WT cells, PS dKO cells showed also prominent localization of the receptor at the plasma membrane. Reexpression of hPS1 in PS dKO cells decreased the localization of LDLR at the cell surface and led to predominant localization in juxtanuclear compartments, very similar to WT cells (Fig. 3A). PS dKO cells also appeared to be enlarged compared with WT cells, and reexpression of hPS1 normalized cell size (Fig. 3A). As revealed by cell-surface labeling with biotin, expression of LDLR at the plasma membrane was increased in PS-deficient cells (Fig. 3B).

The increased expression of LDLR at the cell surface but decreased uptake of LDL after inhibition of $\gamma$-secretase suggested impaired endocytosis of LDLR. The analysis of LDLR endocytosis indeed revealed reduced internalization from the plasma membrane in PS-deficient cells (Fig. 3C). We also compared the LDLR endocytosis in HEK293 cells stably overexpressing WT or a DN mutant of PS1. LDLR endocytosis was found to be reduced in cells expressing PS1-DN compared with the cells which express PS1 WT (Fig. 3D). These results indicate that loss of $\gamma$-secretase activity rather than loss of PS proteins causes an inhibition of LDLR endocytosis in PS-deficient cells.

\section{Increased apolipoprotein $\mathrm{E}$ in brain of mice with neuron- specific deletion of PS1}

To prove a role of $\gamma$-secretase in lipoprotein metabolism in vivo, we analyzed apo E levels in brain homogenates of mice with a conditional deletion of PS1 in brain neurons (PS1n ${ }^{-1-}$ ) and control mice (Dewachter et al., 2002). Brain apo E levels were significantly increased in the PS1n ${ }^{-1-}$ mice compared with controls, suggesting an involvement of $\gamma$-secretase in the metabolism of apo E (Fig. 4A). Immunohistochemical analysis revealed that neuronal deficiency of PS1 also resulted in altered localization of apo E. In control mice, apo E was homogenously distributed in the cytoplasm of cortical neurons, indicating efficient internalization. In contrast, neurons of PS1 ${ }^{-1-}$ mice showed decreased cytoplasmic apo E staining, but prominent reactivity at the plasma membrane (Fig. 4B,C). These data indicate that the uptake of apo E is impaired in PS1-deficient neurons in vivo.

Recently, it was reported that the APP intracellular domain (AICD) could regulate the expression of the LDL receptor related protein 1 (LRP1), and increased levels of LRP1 mRNA and protein were found in brains of APP-deficient mice (Liu et al., 2007). Because PS deficiency would lead to decreased AICD production, the lack of AICD after inactivation of $\gamma$-secretase could affect the expression of LRP1. We therefore compared LRP1 mRNA expression in brain cortices of embryonic WT mice with that of mice lacking APP and APP like proteins (APLP) 1 or 2 (DKO, $\mathrm{APP}^{-1-} / \mathrm{APLP}^{-/-}$double knock-out; TKO, $\mathrm{APP}^{-/-} / \mathrm{APLP}^{-/-}$/ APLP2 ${ }^{-1-}$ triple knock-out). In contrast to previous data (Liu et al., 2007), levels of LRP1 mRNA were not increased after deletion of APP and APLPs (Fig. 5A). Rather, there was a trend to decreased expression of LRP1 mRNA, suggesting that AICD does not suppress transcription of LRP1. In line with this, LRP1 mRNA expression was not increased in embryonic brain cortices 
of PS1 KO mice (data not shown). To test a potential role of AICD in adult mice, we compared the levels of LRP1 mRNA and protein in brains of 22-26 weeks old WT mice with that of age-matched mice deficient in APP $\left(\mathrm{APP}^{-/-}\right)$or APLP2 $\left(\mathrm{APLP}^{-/-}\right)$. Because $\mathrm{APP}^{-/-} / \mathrm{APLP}^{-/-}$ double knock-out mice show early postnatal death (Heber et al., 2000), we also generated mice that express soluble APP $(\mathrm{APP} s)$ in a APLP2 ${ }^{-/-}$background by crossing APPs $\alpha$ knock-in mice with APLP2 ${ }^{-/-}$mice. The resulting $\operatorname{APPs} \alpha /$ APLP2 ${ }^{-1-}$ (DKI) mice lack the intracellular domains of APP and APLP2, but express the soluble ectodomain of APP. Notably, APPs $\alpha / A P L P 2^{-/-}$mice escape early postnatal death, indicating an important physiological function of the APP ectodomain. Whereas LRP1 mRNA was not significantly altered in brains of APLP $2^{-1-}$ and APPs $\alpha /$ APLP2 ${ }^{-/-}$mice, a slight $(1.75$-fold) increase in brains of adult APP ${ }^{-1-}$ mice was detected (Fig. $5 B$ ). These data indicate that lack of AICD does not increase the mRNA expression of LRP1. A potential role of the APP ectodomain in this process remains to be determined in the further studies.

Western immunoblot analysis demonstrated that expression of LRP1 was not increased in the brains of adult $\mathrm{APP}^{-1-}$, $\mathrm{APLP}^{-/-}$, or APPs $\alpha / \mathrm{APLP}^{-/-}$mice compared with WT mice (Fig. 5C,D). Importantly, brain levels of apo E were also not altered in the different models, even in the APPs $\alpha /$ APLP2 ${ }^{-/-}$mice that lack ICDs of APP and APLP2 (Fig. 5C-E). Together, these data indicate that lack of AICD is not responsible for the increased levels of apo E observed in the brains of PS1n ${ }^{-1-}$ mice (see Fig. 4).

\section{Increased apo $\mathrm{E}$ in mouse and human brain with PS1 FAD mutations}

We next tested the effect of FADassociated PS1 mutations on apo E expression in the brain of transgenic mice. Of note, mice were used that do not overexpress human APP and therefore do not develop deposits of $A \beta$ (Dewachter et al., 2002). Western immunoblotting revealed significantly elevated levels of apo $\mathrm{E}$ in brain lysates of PS1 A246E (Fig. 6A). Very similar data were also obtained with mice expressing the PS1 $\Delta \mathrm{E} 9$ mutation (Fig. $6 B$ ). To verify these findings in humans, we compared the expression of apo E in brains of FAD cases harboring mutations in the PS1 gene to that of controls. Apo E levels were markedly increased in brain lysates of FAD patients compared to controls (Fig. 6C,D).

\section{Accumulation of $\gamma$-secretase substrates reduces endocytosis of LDLR}

Because our data so far did not support an involvement of cleavage products that derive from proteolytic processing of APP by ${ }^{* *} p<0.01$.
B
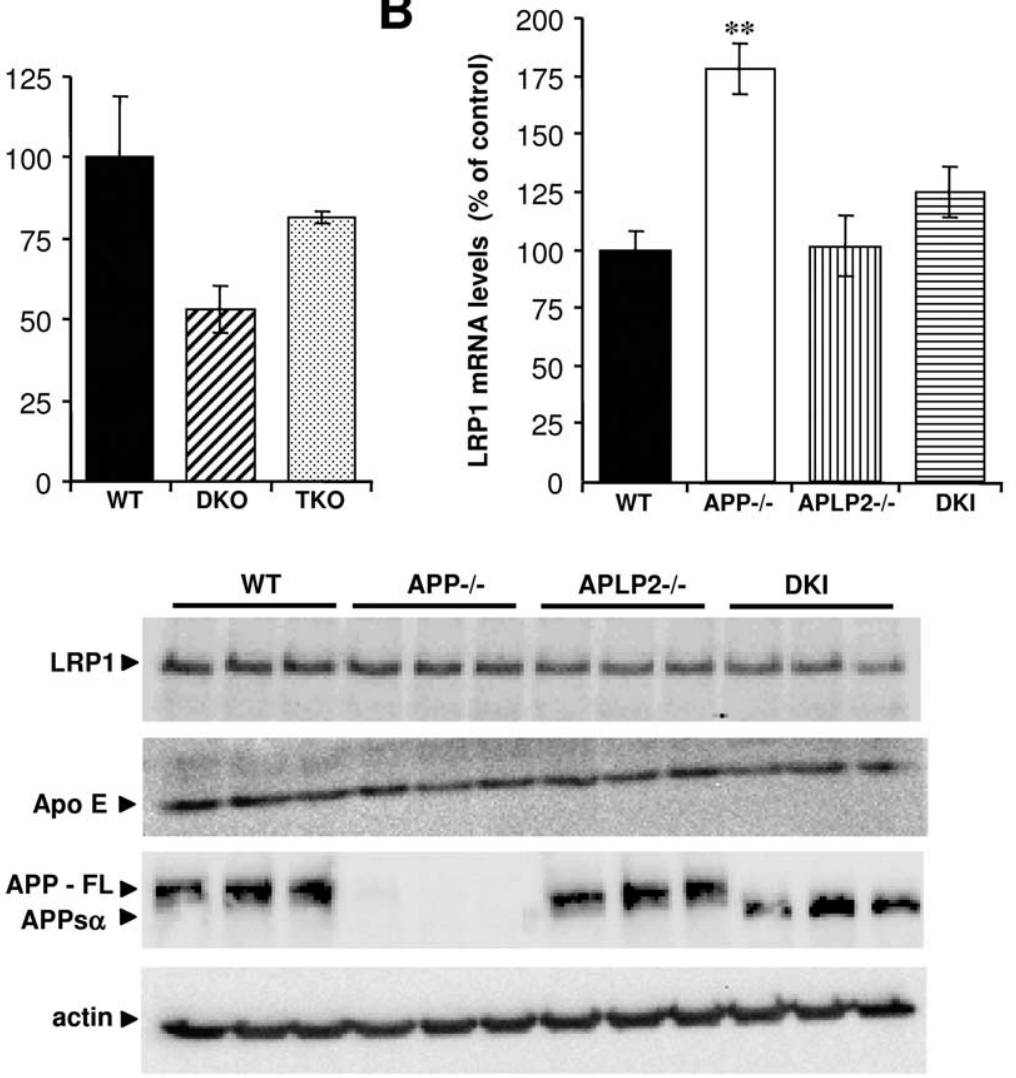

$\mathbf{E}$

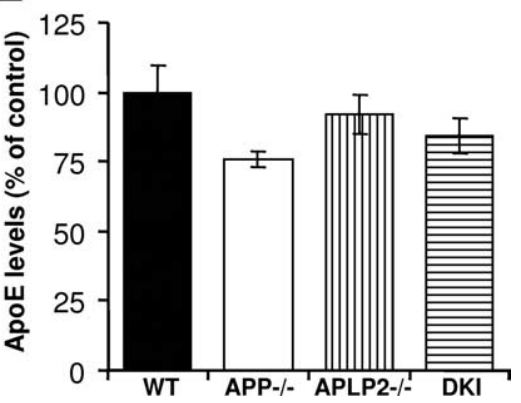

Figure 5. Deletion of AICD does not increase LRP1 expression in mouse brain. $A, L R P 1 \mathrm{mRNA}$ expression analysis by qRT-PCR at embryonic day 15.5 in WT ( $n=4)$, APP/APLP2 double knock-out (DK0; $n=4)$, and APP/APLP1/APLP3 triple knock-out (TK0; $n=$ 4) mice brains. $\boldsymbol{B}$, Expression analysis of LRP1 mRNA by qRT-PCR in brains of 22- to 24-week-old mice [WT ( $n=7)$, APP-KO $(n=$ , WT $(n=7)$, APP-KO $(n=3)$, APLP2-KO $(n=7)$, and DKI $(n=7)$ mice by Western immunoblotting. $\boldsymbol{D}$, $\boldsymbol{E}$, Quantitation of LRP1 D) and apo $\mathrm{E}(\boldsymbol{E})$ expression by ECL imaging. Details are described in Materials and Methods. Values represent means $\pm S D$.

$\gamma$-secretase in the regulation of LDLR endocytosis, we tested the role of APP CTFs, the immediate $\gamma$-secretase substrate. Consistent with previous studies (De Strooper et al., 1998; Wolfe et al., 1999a; Wolfe et al., 1999b), we observed a strong accumulation of APP CTFs in PS-deficient cells and after inhibition of $\gamma$-secretase activity by DAPT (supplemental Fig. 6, available at www. jneurosci.org as supplemental material). Importantly, APP CTFs accumulated at the cell surface and in cytoplasmic vesicles after inhibition of $\gamma$-secretase with DAPT or in PS-deficient cells. Similar patterns were also observed for the $\gamma$-secretase substrates LRP1-CT and N $\Delta \mathrm{E}$ (supplemental Fig. 6, available at www. jneurosci.org as supplemental material). Consistent with earlier studies (Bentahir et al., 2006; Kumar-Singh et al., 2006) we also 


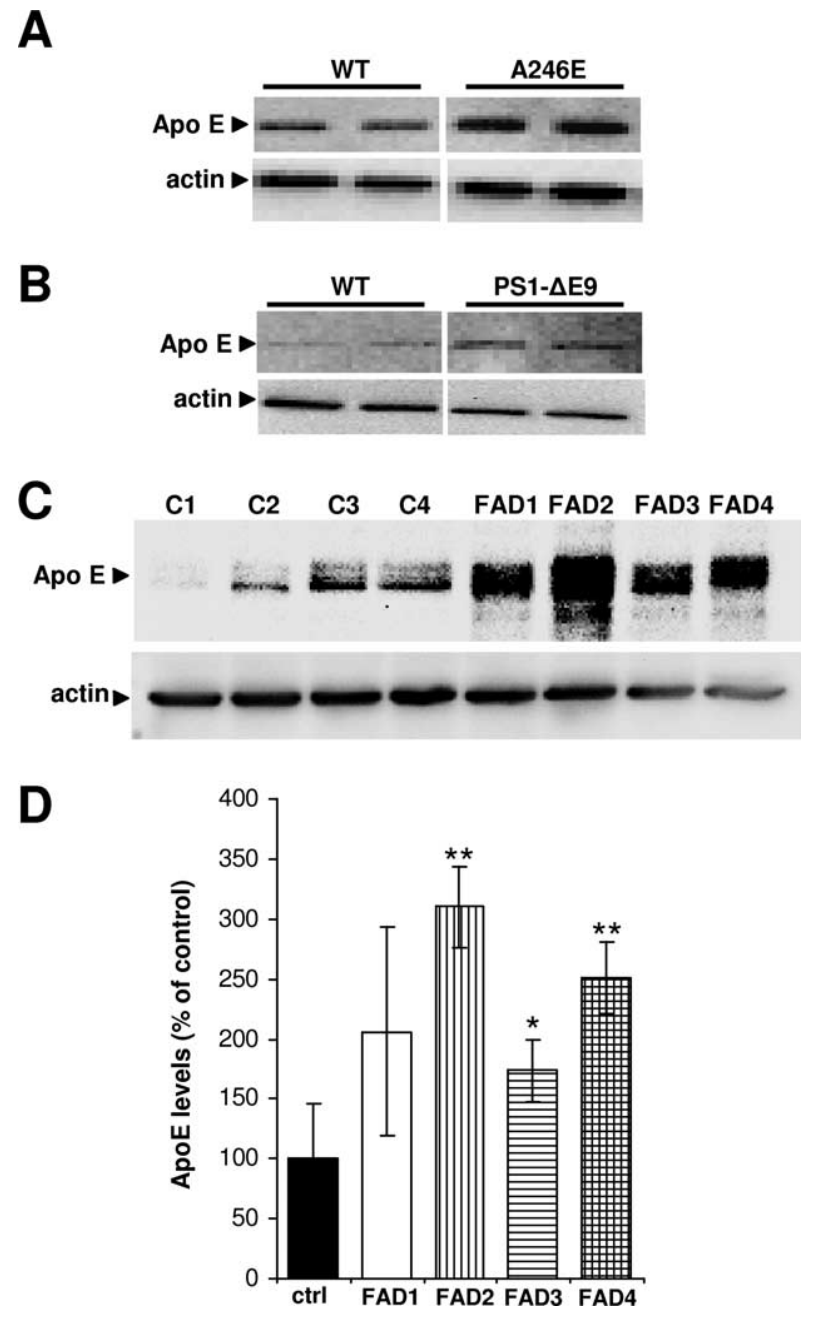

Figure 6. Increased levels of apo Ein brains of PS1 FAD mutant mice. $A$, Western blot analysis of apo Elevels in brains of WT and PS1 A246E mutant mice at age of 10 month. Quantitative ECL imaging revealed significantly increased levels in PS1 A246E mice [161.8 $\pm 55.4 \%(n=5)$ vs $100 \pm 20.5 \%(n=5) ; p<0.05]$. $\boldsymbol{B}$, Western blot analysis of apo E in brains of mice expressing PS1 WT or PS1- $\triangle E 9$ at age of 6 month. The effects on apo $E$ were sex independent. $C, D$, Detection of apo $E$ in human brains from control individuals and patients with familial $A D$ harboring mutations in the PS1 gene by Western immunoblotting (FAD1-L174R, FAD2-T113114 insertion mutation, FAD3-1437V, FAD4-T113-114 insertion mutation). Quantitation of apo E levels in PS1 FAD brain lysates compared with mean apo E levels from four control human brains was done by $E C L$ imaging $(\boldsymbol{D})$. Values represent means of three independent experiments \pm SD. ${ }^{*} p<0.05 ;{ }^{* *} p<0.01$.

observed increased levels of APP-CTFs in cells expressing different PS1 FAD mutants (supplemental Fig. 7, available at www. jneurosci.org as supplemental material), indicating accumulation of $\gamma$-secretase substrates as a result of partial loss of proteolytic function by mutations in PS proteins.

Because the membrane-tethered CTFs of several $\gamma$-secretase substrates contain amino acid motifs that interact with adaptor proteins involved in the endocytosis of cell surface receptors, we conjectured that impaired cleavage of these substrates could affect their targeting and metabolism. Notably, the adaptor proteins Fe65 and autosomal recessive hypercholesterolemia (ARH), which mediate endocytosis of lipoprotein receptors, also interact with the cytoplasmic domain of APP (Trommsdorff et al., 1998; Herz and Bock, 2002). We therefore tested whether accumulation of APP CTFs interferes with the localization of these adaptor proteins at the plasma membrane. In control cells, Fe65 showed prominent localization in the nucleus (Fig. 7A). However, Fe65 was predominantly targeted to juxtanuclear structures after overexpression of APP CTF (C99-EGFP), indicating an interaction of both proteins in these compartments (Fig. 7B). The pharmacological inhibition of $\gamma$-secretase also led to prominent targeting of Fe65 to the plasma membrane together with C99, further indicating aberrant targeting of adaptor proteins as a result of accumulated APP CTFs (Fig. 7B). The localization of ARH was also affected by overexpression of C99-EGFP and subsequent inhibition of $\gamma$-secretase. Whereas ARH showed a broader distribution in cells without C99-EGFP (Fig. 7C), the simultaneous expression of C99-EGFP targeted ARH predominantly to juxtanuclear structures (Fig. 7D). Similar to Fe65, inhibition of $\gamma$-secretase also led to prominent targeting of ARH to the plasma membrane together with C99-EGFP (Fig. 7D).

To prove that accumulation of APP CTFs could impair the function of LDLR, we analyzed receptor endocytosis by biotinylation experiments. The expression of APP-C99 markedly reduced the internalization of LDLR from the cell surface (Fig. 7E), indicating that accumulation of APP CTFs interferes with the subcellular transport of the receptor. Together, these results are consistent with impaired lipoprotein endocytosis by accumulation of APP CTFs after total or partial loss of $\gamma$-secretase function.

\section{Discussion}

Here, we demonstrate that $\gamma$-secretase activity is intimately related to the endocytosis of lipoproteins. The deficiency of PS proteins or FAD-associated mutations decreased the capacity of cells to internalize extracellular lipoproteins by impairment of lipoprotein receptor endocytosis. The comprehensive analysis of cellular sterols and expression of cholesterol biosynthetic enzymes allowed the demonstration of enhanced cholesterol biosynthesis in PS-deficient cells. These data are consistent with previous studies showing that lowering extracellular LDL concentration results in upregulation of cellular cholesterol biosynthesis by increasing expression of HMG-Co A reductase (Brown and Goldstein, 1976). In turn, addition of exogenous LDL to porcine vascular endothelial cells led to suppression of CYP51 mRNA expression via an SREBP-2-dependent pathway (Rodríguez et al., 2001). We also observed increased levels of HMG-CoA reductase and CYP51 in PS-deficient cells, suggesting that the decreased uptake of extracellular LDL led to transcriptional upregulation of these enzymes. Because HMG-CoA reductase is also regulated at the posttranslational level by lanosterol (Goldstein et al., 2006), the decreased concentrations of lanosterol in PS-deficient cells could also stabilize HMG-CoA reductase.

Because $\mathrm{A} \beta$ inhibits HMG-CoA reductase activity in vitro, the lack of $\mathrm{A} \beta$ could also increase cholesterol levels in PS-deficient cells (Grimm et al., 2005). However, the addition of exogenous $\mathrm{A} \beta$ did neither normalize the elevated cholesterol levels nor the decreased lanosterol levels of PS-deficient cells. It will therefore be interesting to further dissect the relative contribution of $\mathrm{A} \beta$ in cellular cholesterol metabolism.

In line with the impaired lipoprotein uptake, conditional deletion of neuronal PS1 led to increased levels of apo E in mouse brain. Because apo $\mathrm{E}$ is mainly synthesized by glial cells that were not targeted by deletion of PS1 in neurons (Dewachter et al., 2002), these data suggest that inefficient clearance of apo E by neuronal cells contributes to increased apo E levels. Whether apo $\mathrm{E}$ is also altered at the transcriptional level in these models remains to be determined. Importantly, PS1 FAD mutations also led to increased levels of apo $\mathrm{E}$ in mouse brain. Because apo $\mathrm{E}$ 
A

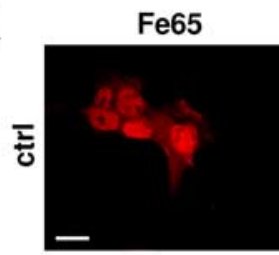

C

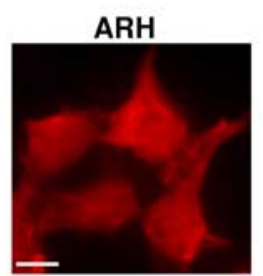

D
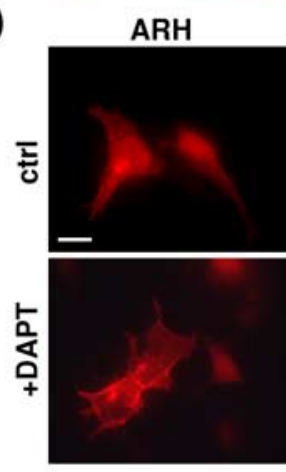

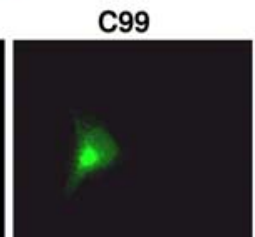

DAPI
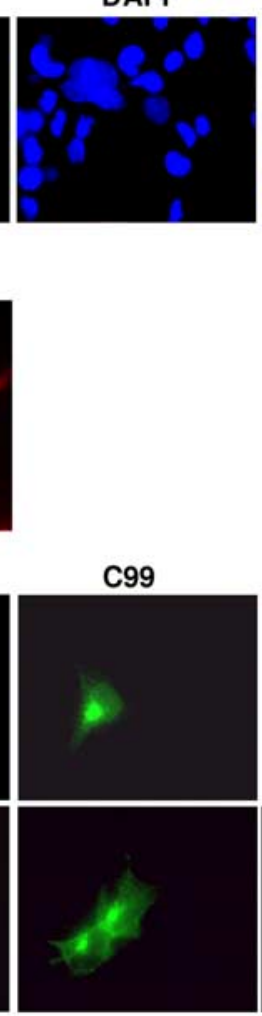

overlay

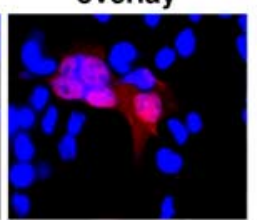

overlay
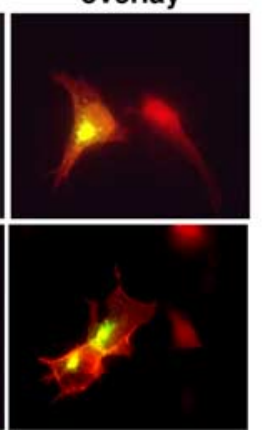

B

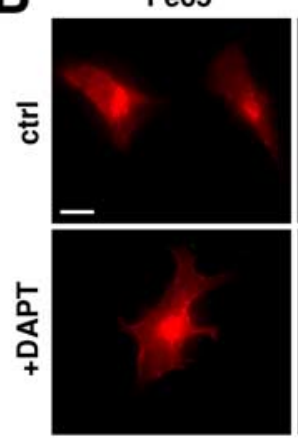

C99
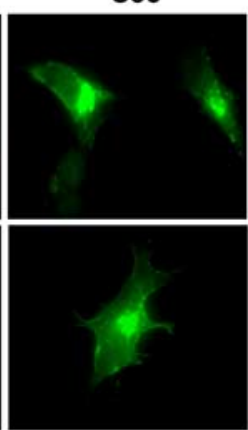

E
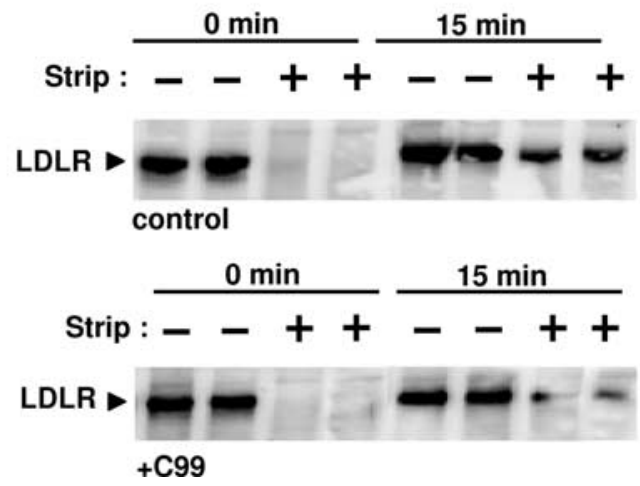

Figure 7. Accumulation of APP CTFs causes mistargeting of adaptor proteins and decreased endocytosis of LDLR. A, HEK293 cells were transfected with cDNA encoding myc-tagged Fe65. After $48 \mathrm{~h}$, cells were fixed, permeabilized, and stained for Fe65 with anti-myc antibody 9E10. Cells were counterstained with DAPI to localize nuclei. $\boldsymbol{B}$, Cells were transfected with CDNAs encoding APP C99-EGFP and myc-tagged Fe65, and then incubated in the presence (bottom) or absence (top) of $10 \mu \mathrm{m}$ DAPT. Expression of C99-EGFP caused relocalization of Fe65 to juxtanuclear compartments (top). In the presence of DAPT, prominent staining at the cell surface was also observed (bottom). C, D, APP (TF-dependent localization of ARH. HEK293 cells were transfected with cDNA encoding ARH alone $(\boldsymbol{C})$ or together with APP (99-EGFP (D). Cells were incubated the presence ( $\boldsymbol{D}$, bottom) and absence $(\boldsymbol{D}$, top) of $10 \mu \mathrm{m}$ DAPT. Scale bars in $\boldsymbol{A}-\boldsymbol{D}, 15 \mu \mathrm{m}$. $\boldsymbol{E}$, LDLR endocytosis in HEK293 control cells and in cells expressing APP $(99$ was analyzed by biotinylation as described under Materials and Methods. Quantitative ECL imaging revealed that $C 99$ expression resulted in significantly decreased endocytosis of $\operatorname{LDLR}(34.3 \pm 18.0 \%$ vs $100 \pm 11.6 \% ; p<0.05)$.

together with lipoprotein receptors also mediate $\mathrm{A} \beta$ clearance within the brain and through the blood-brain barrier (Kang et al., 2000; Shibata et al., 2000; Van Uden et al., 2002), impaired $\gamma$-secretase function might affect $\mathrm{A} \beta$ clearance. On the other hand, apo $\mathrm{E}$ also seems to alter the ratio of $\mathrm{A} \beta 40 / \mathrm{A} \beta 42$, and promote aggregation and deposition of $\mathrm{A} \beta$ (Bales et al., 2002; Holtzman, 2003; Dolev and Michaelson, 2006). Thus, the inefficient clearance of apo E could contribute to increased deposition of $\mathrm{A} \beta$ in PS-dependent FAD. Together, our data provide a potential link between mutations in PS that cause early-onset AD and apo $\mathrm{E}$ that is critically involved in late-onset $\mathrm{AD}$ (Tanzi and Bertram, 2005). It is therefore intriguing to speculate that apo E-dependent lipid metabolism and $\mathrm{A} \beta$ clearance in the brain contribute to the pathogenesis of early-onset FAD caused by PS mutations.

A recent study indicated that AICD could suppress LRP1 transcription (Liu et al., 2007). In addition, the increased LRP1 expression in APP KO cells and embryonic mouse brain was associated with enhanced metabolism of apo E and decreased apo E levels (Liu et al., 2007). Our data do not support a role of AICD in the transcriptional regulation of LRP1. No significant changes in LRP1 mRNA levels were observed in brains of embryonic APP/ APLP1/APLP2 triple KO mice that lack ICDs of all members of the APP family. However, a slight increase in LRP1 mRNA levels in brains of adult APP KO mice was detected. Because this increase was not seen in APPs $\alpha /$ APLP $^{-/-}$(DKI) mice, which lack the ICDs of APP and APLP2 but express soluble APP, these data rather could suggest an involvement of the APP ectodomain in the regulation of LRP1 mRNA expression. It might therefore be interesting to investigate a potential role of the APP ectodomain in the regulation of LRP1 mRNA expression in the future. Importantly, the protein levels of LRP1 and apo $\mathrm{E}$ in adult $\mathrm{APP}^{-/-}$, ALPL2 ${ }^{-1-}$, and APPs $\alpha / A P L P 2^{-1-}$ mice were not altered compared with WT mice, further indicating that ICDs of APP or APLPs do not play a major role in the regulation of LRP1 and apo E metabolism. The reasons for the different findings of the previous (Liu et al., 2007) and this study remain unclear, but could arise by usage of different transgenic models and methods to detect LRP1 and apo E.

Because neurons are dependent on the uptake of extracellular cholesterol from lipoprotein particles (Herz and Bock, 2002; Pfrieger, 2003), the present findings might be especially relevant for neuronal dysfunction in PS-associated FAD. The decreased uptake of apo $\mathrm{E}$ and cholesterol in neurons with impaired $\gamma$-secretase activity could impair cholesterol-dependent processes, including dendrite differentiation and synaptogenesis (Mauch et al., 2001; Pfrieger, 2002).

PS proteins have been previously implicated in the subcellular trafficking of membrane proteins, including tyrosinase, nicastrin, N-cadherin, and telencephalin (Annaert et al., 2001; Wang et al., 2006; Zhang et al., 2006; Parks and Curtis, 2007). Consistent with our data, the endocytosis of BSA and APP was also 
found to be decreased in PS-deficient cells (Kaether et al., 2002; Wood et al., 2005), but the underlying molecular mechanisms were unclear. We show that accumulation of APP CTFs caused aberrant targeting of Fe65 and ARH to the plasma membrane. Thus, accumulated APP CTFs could engage a significant pool of these adaptor proteins, thereby compromising endocytosis of cell surface proteins.

Increased levels of APP CTFs have also been observed in cells expressing FAD-associated mutations in APP (McPhie et al., 1997). Because APP CTFs impair $\mathrm{Ca}^{2+}$ homeostasis, long-term potentiation, and inflammatory processes (Yankner et al., 1989; Berger-Sweeney et al., 1999; Lahiri et al., 2002; Chang and Suh, 2005), their accumulation could contribute to neuronal dysfunction in AD. Indeed, mice with PS deficiency in forebrain neurons show age-dependent accumulation of APP CTFs and neurodegeneration (Herms et al., 2003; Saura et al., 2004), which because of the lack of $\gamma$-secretase could not be attributed to toxic effects of $\mathrm{A} \beta$. Our data indicate that accumulation of these CTFs by (partial) loss of $\gamma$-secretase function also impairs lipoprotein uptake and cellular cholesterol homeostasis which might, in addition to altered $\mathrm{A} \beta$ production, contribute to the pathogenesis of $\mathrm{AD}$.

The number of known $\gamma$-secretase substrates is steadily increasing and includes cell adhesion molecules, surface receptors, and channel proteins (Wolfe and Kopan, 2004; Parks and Curtis, 2007). The ICDs released after $\gamma$-secretase cleavage of Notch, $\mathrm{N}$ and E-cadherin, and ErbB4 could regulate gene transcription after translocation to the nucleus (Marambaud et al., 2003; Koo and Kopan, 2004). Although AICD could affect gene transcription by association with Fe65 in vitro, its release from cellular membranes by $\gamma$-secretase appears to be not absolutely required (Biederer et al., 2002; Cao and Sudhof, 2004; Hass and Yankner, 2005). Thus, the $\gamma$-secretase-dependent cleavage of APP CTFs and probably other substrates might not be important for nuclear signaling, but rather serve for degradation of certain membrane proteins (Kopan and Ilagan, 2004; Sambamurti et al., 2006; Selkoe and Wolfe, 2007). Accumulation of other $\gamma$-secretase substrates might therefore also contribute to the pathogenesis of $\mathrm{AD}$.

\section{References}

Annaert WG, Esselens C, Baert V, Boeve C, Snellings G, Cupers P, Craessaerts K, De Strooper B (2001) Interaction with telencephalin and the amyloid precursor protein predicts a ring structure for presenilins. Neuron 32:579-589.

Bales KR, Dodart JC, DeMattos RB, Holtzman DM, Paul SM (2002) Apolipoprotein E, amyloid, and Alzheimer disease. Mol Interv 2:363-375.

Bentahir M, Nyabi O, Verhamme J, Tolia A, Horré K, Wiltfang J, Esselmann H, De Strooper B (2006) Presenilin clinical mutations can affect gamma-secretase activity by different mechanisms. J Neurochem 96:732-742.

Berger-Sweeney J, McPhie DL, Arters JA, Greenan J, Oster-Granite ML, Neve RL (1999) Impairments in learning and memory accompanied by neurodegeneration in mice transgenic for the carboxyl-terminus of the amyloid precursor protein. Brain Res Mol Brain Res 66:150-162.

Biederer T, Cao X, Südhof TC, Liu X (2002) Regulation of APP-dependent transcription complexes by Mint/X11s: differential functions of Mint isoforms. J Neurosci 22:7340-7351.

Brown MS, Goldstein JL (1976) Receptor-mediated control of cholesterol metabolism. Science 191:150-154.

Brown MS, Goldstein JL (1997) The SREBP pathway: regulation of cholesterol metabolism by proteolysis of a membrane-bound transcription factor. Cell 89:331-340.

Cao X, Südhof TC (2004) Dissection of amyloid-beta precursor proteindependent transcriptional transactivation. J Biol Chem 279:24601-24611.

Capell A, Steiner H, Romig H, Keck S, Baader M, Grim MG, Baumeister R, Haass C (2000) Presenilin-1 differentially facilitates endoproteolysis of the beta-amyloid precursor protein and Notch. Nat Cell Biol 2:205-211.

Chang KA, Suh YH (2005) Pathophysiological roles of amyloidogenic carboxy-terminal fragments of the beta-amyloid precursor protein in Alzheimer's disease. J Pharmacol Sci 97:461-471.

De Strooper B, Saftig P, Craessaerts K, Vanderstichele H, Guhde G, Annaert W, Von Figura K, Van Leuven F (1998) Deficiency of presenilin-1 inhibits the normal cleavage of amyloid precursor protein. Nature 391:387-390.

Dewachter I, Reversé D, Caluwaerts N, Ris L, Kuipéri C, Van den Haute C, Spittaels K, Umans L, Serneels L, Thiry E, Moechars D, Mercken M, Godaux E, Van Leuven F (2002) Neuronal deficiency of presenilin 1 inhibits amyloid plaque formation and corrects hippocampal long-term potentiation but not a cognitive defect of amyloid precursor protein [V717I] transgenic mice. J Neurosci 22:3445-3453.

Dolev I, Michaelson DM (2006) The nucleation growth and reversibility of amyloid-beta deposition in vivo. J Alzheimers Dis 10:291-301.

Goldstein JL, DeBose-Boyd RA, Brown MS (2006) Protein sensors for membrane sterols. Cell 124:35-46.

Grimm MO, Grimm HS, Pätzold AJ, Zinser EG, Halonen R, Duering M, Tschäpe JA, De Strooper B, Müller U, Shen J, Hartmann T (2005) Regulation of cholesterol and sphingomyelin metabolism by amyloid-beta and presenilin. Nat Cell Biol 7:1118-1123.

Hass MR, Yankner BA (2005) A \{gamma\}-secretase-independent mechanism of signal transduction by the amyloid precursor protein. J Biol Chem 280:36895-36904.

Heber S, Herms J, Gajic V, Hainfellner J, Aguzzi A, Rülicke T, von Kretzschmar H, Von Koch C, Sisodia S, Tremml P, Lipp HP, Wolfer DP, Müller U (2000) Mice with combined gene knock-outs reveal essential and partially redundant functions of amyloid precursor protein family members. J Neurosci 20:7951-7963.

Herms J, Schneider I, Dewachter I, Caluwaerts N, Kretzschmar H, Van Leuven F (2003) Capacitive calcium entry is directly attenuated by mutant presenilin-1, independent of the expression of the amyloid precursor protein. J Biol Chem 278:2484-2489.

Herms J, Anliker B, Heber S, Ring S, Fuhrmann M, Kretzschmar H, Sisodia S, Müller U (2004) Cortical dysplasia resembling human type 2 lissencephaly in mice lacking all three APP family members. EMBO J 23:4106-4115.

Herreman A, Serneels L, Annaert W, Collen D, Schoonjans L, De Strooper B (2000) Total inactivation of gamma-secretase activity in presenilindeficient embryonic stem cells. Nat Cell Biol 2:461-462.

Herz J, Bock HH (2002) Lipoprotein receptors in the nervous system. Annu Rev Biochem 71:405-434.

Holtzman DM (2003) Potential role of endogenous and exogenous amyloid-beta binding molecules in the pathogenesis, diagnosis, and treatment of Alzheimer disease. Alzheimer Dis Assoc Disord 17:151-153.

Jeon H, Blacklow SC (2005) Structure and physiologic function of the lowdensity lipoprotein receptor. Annu Rev Biochem 74:535-562.

Kaether C, Lammich S, Edbauer D, Ertl M, Rietdorf J, Capell A, Steiner H, Haass C (2002) Presenilin-1 affects trafficking and processing of betaAPP and is targeted in a complex with nicastrin to the plasma membrane. J Cell Biol 158:551-561.

Kaether C, Schmitt S, Willem M, Haass C (2006) Amyloid precursor protein and notch intracellular domains are generated after transport of their precursors to the cell surface. Traffic 7:408-415.

Kang DE, Pietrzik CU, Baum L, Chevallier N, Merriam DE, Kounnas MZ, Wagner SL, Troncoso JC, Kawas CH, Katzman R, Koo EH (2000) Modulation of amyloid beta-protein clearance and Alzheimer's disease susceptibility by the LDL receptor-related protein pathway. J Clin Invest 106:1159-1166.

Kennedy JL, Farrer LA, Andreasen NC, Mayeux R, St George-Hyslop P (2003) The genetics of adult-onset neuropsychiatric disease: complexities and conundra? Science 302:822-826.

Koo EH, Kopan R (2004) Potential role of presenilin-regulated signaling pathways in sporadic neurodegeneration. Nat Med 10 [Suppl]:S26-S33.

Kopan R, Ilagan MX (2004) Gamma-secretase: proteasome of the membrane? Nat Rev Mol Cell Biol 5:499-504.

Kumar-Singh S, Theuns J, Van Broeck B, Pirici D, Vennekens K, Corsmit E, Cruts M, Dermaut B, Wang R, Van Broeckhoven C (2006) Mean ageof-onset of familial Alzheimer disease caused by presenilin mutations correlates with both increased Abeta42 and decreased Abeta40. Hum Mutat 27:686-695.

Lahiri DK, Kotwal GJ, Farlow MR, Sima A, Kupsky W, Sarkar FH, Sambamurti K (2002) The role of the carboxyl-terminal fragments of amyloid precursor protein in Alzheimer's disease. Ann N Y Acad Sci 973:334-339. Lee MK, Borchelt DR, Kim G, Thinakaran G, Slunt HH, Ratovitski T, Martin 
LJ, Kittur A, Gandy S, Levey AI, Jenkins N, Copeland N, Price DL, Sisodia SS (1997) Hyperaccumulation of FAD-linked presenilin 1 variants in vivo. Nat Med 3:756-760.

Liu Q, Zerbinatti CV, Zhang J, Hoe HS, Wang B, Cole SL, Herz J, Muglia L, Bu G (2007) Amyloid precursor protein regulates brain apolipoprotein E and cholesterol metabolism through lipoprotein receptor LRP1. Neuron 56:66-78.

Marambaud P, Wen PH, Dutt A, Shioi J, Takashima A, Siman R, Robakis NK (2003) A CBP binding transcriptional repressor produced by the PS1/ epsilon-cleavage of N-cadherin is inhibited by PS1 FAD mutations. Cell 114:635-645.

Mauch DH, Nägler K, Schumacher S, Göritz C, Müller EC, Otto A, Pfrieger FW (2001) CNS synaptogenesis promoted by glia-derived cholesterol. Science 294:1354-1357.

McPhie DL, Lee RK, Eckman CB, Olstein DH, Durham SP, Yager D, Younkin SG, Wurtman RJ, Neve RL (1997) Neuronal expression of beta-amyloid precursor protein Alzheimer mutations causes intracellular accumulation of a C-terminal fragment containing both the amyloid beta and cytoplasmic domains. J Biol Chem 272:24743-24746.

Mishra SK, Watkins SC, Traub LM (2002) The autosomal recessive hypercholesterolemia (ARH) protein interfaces directly with the clathrin-coat machinery. Proc Natl Acad Sci U S A 99:16099-16104.

Naruse S, Thinakaran G, Luo JJ, Kusiak JW, Tomita T, Iwatsubo T, Qian X, Ginty DD, Price DL, Borchelt DR, Wong PC, Sisodia SS (1998) Effects of PS1 deficiency on membrane protein trafficking in neurons. Neuron 21:1213-1221.

Noviello C, Vito P, Lopez P, Abdallah M, D’Adamio L (2003) Autosomal recessive hypercholesterolemia protein interacts with and regulates the cell surface level of Alzheimer's amyloid beta precursor protein. J Biol Chem 278:31843-31847.

Nyabi O, Pype S, Mercken M, Herreman A, Saftig P, Craessaerts K, Serneels L, Annaert W, De Strooper B (2002) No endogenous A beta production in presenilin-deficient fibroblasts. Nat Cell Biol 4:E164; author reply E165-E166.

Päivä H, Thelen KM, Van Coster R, Smet J, De Paepe B, Mattila KM, Laakso J, Lehtimäki T, von Bergmann K, Lütjohann D, Laaksonen R (2005) High-dose statins and skeletal muscle metabolism in humans: a randomized, controlled trial. Clin Pharmacol Ther 78:60-68.

Parks AL, Curtis D (2007) Presenilin diversifies its portfolio. Trends Genet 23:140-150.

Pfrieger FW (2002) Role of glia in synapse development. Curr Opin Neurobiol 12:486-490.

Pfrieger FW (2003) Cholesterol homeostasis and function in neurons of the central nervous system. Cell Mol Life Sci 60:1158-1171.

Pietrzik CU, Busse T, Merriam DE, Weggen S, Koo EH (2002) The cytoplasmic domain of the LDL receptor-related protein regulates multiple steps in APP processing. EMBO J 21:5691-5700.

Pietrzik CU, Yoon IS, Jaeger S, Busse T, Weggen S, Koo EH (2004) FE65 constitutes the functional link between the low-density lipoprotein receptor-related protein and the amyloid precursor protein. J Neurosci 24:4259-4265.

Ring S, Weyer SW, Kilian SB, Waldron E, Pietrzik CU, Filippov MA, Herms J, Buchholz C, Eckman CB, Korte M, Wolfer DP, Müller UC (2007) The secreted beta-amyloid precursor protein ectodomain APPs alpha is sufficient to rescue the anatomical, behavioral, and electrophysiological abnormalities of APP-deficient mice. J Neurosci 27:7817-7826.

Rodríguez C, Martínez-González J, Sánchez-Gómez S, Badimon L (2001) LDL downregulates CYP51 in porcine vascular endothelial cells and in the arterial wall through a sterol regulatory element binding protein-2dependent mechanism. Circ Res 88:268-274.

Sambamurti K, Suram A, Venugopal C, Prakasam A, Zhou Y, Lahiri DK, Greig NH (2006) A partial failure of membrane protein turnover may cause Alzheimer's disease: a new hypothesis. Curr Alzheimer Res 3:81-90.

Saura CA, Choi SY, Beglopoulos V, Malkani S, Zhang D, Shankaranarayana Rao BS, Chattarji S, Kelleher RJ 3rd, Kandel ER, Duff K, Kirkwood A, Shen J (2004) Loss of presenilin function causes impairments of memory and synaptic plasticity followed by age-dependent neurodegeneration. Neuron 42:23-36.

Schmidt SD, Nixon RA, Mathews PM (2005) ELISA method for measurement of amyloid-beta levels. Methods Mol Biol 299:279-297.

Selkoe D, Kopan R (2003) Notch and Presenilin: regulated intramembrane proteolysis links development and degeneration. Annu Rev Neurosci 26:565-597.
Selkoe DJ (2001) Alzheimer's disease: genes, proteins, and therapy. Physiol Rev 81:741-766.

Selkoe DJ, Wolfe MS (2007) Presenilin: running with scissors in the membrane. Cell 131:215-221.

Shen J, Bronson RT, Chen DF, Xia W, Selkoe DJ, Tonegawa S (1997) Skeletal and CNS defects in Presenilin-1-deficient mice. Cell 89:629-639.

Shibata M, Yamada S, Kumar SR, Calero M, Bading J, Frangione B, Holtzman DM, Miller CA, Strickland DK, Ghiso J, Zlokovic BV (2000) Clearance of Alzheimer's amyloid-ss(1-40) peptide from brain by LDL receptorrelated protein-1 at the blood-brain barrier. J Clin Invest 106:1489-1499.

Sisodia SS, St George-Hyslop PH (2002) gamma-Secretase, Notch, Abeta and Alzheimer's disease: where do the presenilins fit in? Nat Rev Neurosci 3:281-290.

Spasic D, Annaert W (2008) Building gamma-secretase: the bits and pieces. J Cell Sci 121:413-420.

Struhl G, Adachi A (2000) Requirements for presenilin-dependent cleavage of notch and other transmembrane proteins. Mol Cell 6:625-636.

Tamboli IY, Prager K, Barth E, Heneka M, Sandhoff K, Walter J (2005) Inhibition of glycosphingolipid biosynthesis reduces secretion of the beta-amyloid precursor protein and amyloid beta-peptide. J Biol Chem 280:28110-28117.

Tanzi RE, Bertram L (2005) Twenty years of the Alzheimer's disease amyloid hypothesis: a genetic perspective. Cell 120:545-555.

Thal DR, Capetillo-Zarate E, Schultz C, Rüb U, Saido TC, Yamaguchi H, Haass C, Griffin WS, Del Tredici K, Braak H, Ghebremedhin E (2005) Apolipoprotein $\mathrm{E}$ co-localizes with newly formed amyloid beta-protein (Abeta) deposits lacking immunoreactivity against $\mathrm{N}$-terminal epitopes of Abeta in a genotype-dependent manner. Acta Neuropathol 110:459-471.

Trommsdorff M, Borg JP, Margolis B, Herz J (1998) Interaction of cytosolic adaptor proteins with neuronal apolipoprotein $\mathrm{E}$ receptors and the amyloid precursor protein. J Biol Chem 273:33556-33560.

Van Uden E, Mallory M, Veinbergs I, Alford M, Rockenstein E, Masliah E (2002) Increased extracellular amyloid deposition and neurodegeneration in human amyloid precursor protein transgenic mice deficient in receptor-associated protein. J Neurosci 22:9298-9304.

von Koch CS, Zheng H, Chen H, Trumbauer M, Thinakaran G, van der Ploeg LH, Price DL, Sisodia SS (1997) Generation of APLP2 KO mice and early postnatal lethality in APLP2/APP double KO mice. Neurobiol Aging 18:661-669.

Wahle T, Thal DR, Sastre M, Rentmeister A, Bogdanovic N, Famulok M, Heneka MT, Walter J (2006) GGA1 is expressed in the human brain and affects the generation of amyloid $\beta$-peptide. J Neurosci 26:12838-12846.

Walter J, Fluhrer R, Hartung B, Willem M, Kaether C, Capell A, Lammich S, Multhaup G, Haass C (2001) Phosphorylation regulates intracellular trafficking of beta-secretase. J Biol Chem 276:14634-14641.

Wang R, Tang P, Wang P, Boissy RE, Zheng H (2006) Regulation of tyrosinase trafficking and processing by presenilins: partial loss of function by familial Alzheimer's disease mutation. Proc Natl Acad Sci US A 103:353-358.

Wolfe MS, Kopan R (2004) Intramembrane proteolysis: theme and variations. Science 305:1119-1123.

Wolfe MS, Xia W, Moore CL, Leatherwood DD, Ostaszewski B, Rahmati T, Donkor IO, Selkoe DJ (1999a) Peptidomimetic probes and molecular modeling suggest that Alzheimer's gamma-secretase is an intramembrane-cleaving aspartyl protease. Biochemistry 38:4720-4727.

Wolfe MS, Xia W, Ostaszewski BL, Diehl TS, Kimberly WT, Selkoe DJ (1999b) Two transmembrane aspartates in presenilin-1 required for presenilin endoproteolysis and gamma-secretase activity. Nature 398:513-517.

Wong PC, Zheng H, Chen H, Becher MW, Sirinathsinghji DJ, Trumbauer ME, Chen HY, Price DL, Van der Ploeg LH, Sisodia SS (1997) Presenilin 1 is required for Notch1 and DIIl expression in the paraxial mesoderm. Nature 387:288-292.

Wood DR, Nye JS, Lamb NJ, Fernandez A, Kitzmann M (2005) Intracellular retention of caveolin 1 in presenilin-deficient cells. J Biol Chem 280:6663-6668.

Yankner BA, Dawes LR, Fisher S, Villa-Komaroff L, Oster-Granite ML, Neve RL (1989) Neurotoxicity of a fragment of the amyloid precursor associated with Alzheimer's disease. Science 245:417-420.

Zhang M, Haapasalo A, Kim DY, Ingano LA, Pettingell WH, Kovacs DM (2006) Presenilin/gamma-secretase activity regulates protein clearance from the endocytic recycling compartment. FASEB J 20:1176-1178. 